\title{
Predominantly hemorrhagic choroidal neovascular lesion from exsudative age-related macular degeneration treated with intravitreal ranibizumab therapy \\ Lesão neovascular predominantemente hemorrágica da degeneração macular relacionada à idade, tratada com ranibizumab intravítrea
}

Miguel Hage Amaro'; Aaron Brock Holler²

\section{ABSTRACT}

The authors relate a predominantly hemorrhagic choroidal neovascular lesion from neovascular. Age-related macular degeneration patient case treated with intravitreal ranibizumab therapy. Monthly ranibizumab (six intravitreal injections) displayed a promising response but this limited report is insufficient to guarantee the indication for all predominantly hemorrhagic choroidal neovascular lesion from neovascular age-related macular degeneration. Further studies will be necessary for complete validation of our results for all predominantly hemorrhagic choroidal neovascular lesions from CNV due to AMD.

Keywords: Macular degeneration/drug therapy; Choroidal neovascularization/drug therapy; Angiogenesis inhibitors/therapeutic use; Antibodies monoclonal; Case reports

\section{ReSUmo}

Os autores apresentam um caso de paciente com lesão neovascular predominantemente hemorrágica com degeneração macular relacionada à idade, tratada mensalmente com injenções intravítrea com ranibizumab. Discutem sua evolução, que apesar da boa resposta terapêutica, necessita de maiores estudos para confirmação de seus resultados.

Descritores: Degeneração macular /quimioterapia; Neovascularização coroidal/quimioterapia; Inibidores da angiogênese/uso terapêutico; Anticorpos monoclonais/uso terapêutico; Relato de casos

\footnotetext{
1 Private Practice. Belém (PA) Brazil;

${ }^{2}$ Retina Service, University of lowa, USA.

Study carried out at Retina Service, University of lowa, USA
}

The authors declare no conflicts of interest

Recebido para publicação em: 22/7/2011 - Aceito para publicação em: 10/6/2012 


\section{INTRODUCTION}

$\mathbf{P}$ redominantly hemorrhagic choroidal neovascular lesions are defined as present when at least $50 \%$ of the choroidal neovascular lesion is occupied by blood under the retina ${ }^{(1,2)}$. Predominantly hemorrhagic choroidal neovascular lesions are caused by choroidal neovascularization (CNV) from agerelated macular degeneration (AMD) and display a poor prognosis. ${ }^{1-4}$ At three years of follow-up, the visual outcomes in such cases are reported to be 20/1700 and patients have lost an average of 3.5 lines of Snellen visual acuity (VA) ${ }^{(3,4)}$. The hemorrhage thickness impacts more highly on the final visual acuity than the hemorrhage area, although both display significant visual effects ${ }^{(3)}$. One mechanism of damage is from a subretinal blood barrier effect that prevents photoreceptors from receiving metabolic support from the retinal pigment epithelium and choroids. ${ }^{3,5}$ The natural course of hemorrhages improve in those not affected by AMD, even in thick hemorrhages, although some experimental models have shown irreversible photoreceptor damage ${ }^{(5)}$.

The visual prognosis improves when the hemorrhage is subretinal, as compared to below the retinal pigment epithelium (RPE), in that when patients with subretinal neovascularization from AMD bleed, the blood spreads beneath the RPE and penetrates the subretinal space ${ }^{(6,7)}$. In other conditions, such as trauma or the presumed ocular histoplasmosis syndrome, the hemorrhage is present almost exclusively in the subretinal space. ${ }^{6,7}$

No randomized clinical trials have provided an effective treatment for predominantly hemorrhagic lesions. Submacular surgical trials (SST) found that evacuation of the hemorrhage and associated CNV did not improve or stabilize vision ${ }^{(2)}$. The pneumatic displacement of the hemorrhage to avoid possible photoreceptor toxicity and allow visualization of the underlying CNV with subsequent photodynamic therapy treatment or intravitreal agents has also been suggested as a treatment approach. However, no definitive evidence of the precise risks and benefits, as compared to no-treatment or intravitreal anti-vascular endothelial growth factors and drugs including ranibizumab or bevacizumab, have been demonstrated ${ }^{(4-16)}$.

The aim of this report was to assess the results of a predominantly hemorrhagic choroidal neovascular lesion from a exsudative AMD patient treated with intravitreal ranibizumab therapy.

\section{Case Report}

A caucasian 78-year old woman who was followed due atrophic geographic AMD (figure 1), right eye color image in both eyes using AREDS formulation displayed a subtle visual loss in her right eye. Through ophthalmological evaluation, the visual acuity was counting fingers in the right eye and 20/200 in the left eye. The anterior segment was unremarkable in both eyes. Fundoscopic examination (figure 2) displayed a predominantly hemorrhagic choroidal neovascular lesion overlying an inferior region of the extense area of a pre-existing geographic AMD. Fluorescein angiography (figure 3 and 4) showed a blockage of fluorescein due to extensive subretinal hemorrhage (predominantly hemorrhagic choroidal neovascular lesions) and dye staining in the residual atrophic area. The stratus OCT presented a central subfield thickness of 649 microns. The patient was treated with monthly intravitreal ranibizumab $(0.5 \mathrm{mg} / 0.05 \mathrm{ml})$, receiving six injections for a total of six months. During this time, Argon green laser photocoagulation around the site of choroidal neovascularization was performed. At the end of the treatment period, the subretinal hemorrhage reabsorbed and subretinal fibrosis developed (figure 5). The visual acuity improved to 20 / 200 in the eye, with no recurrences in the two years of follow-up.

\section{Discussion}

Predominantly hemorrhagic choroidal neovascular lesions due to AMD have not been enrolled in clinical studies. ${ }^{17-20}$ However, randomized trials using photodynamic therapy with

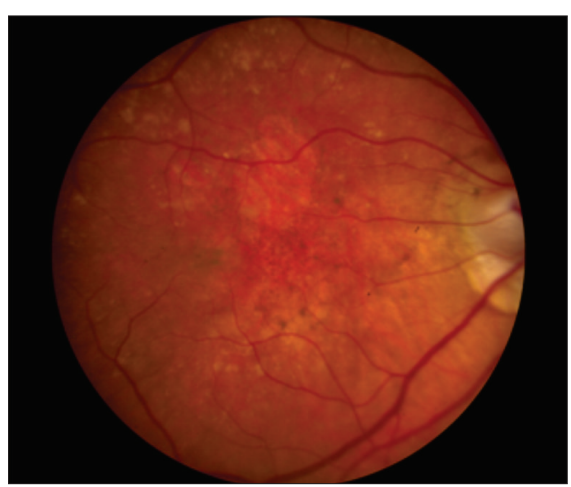

Figure 1: Geographic atrophy from AMD

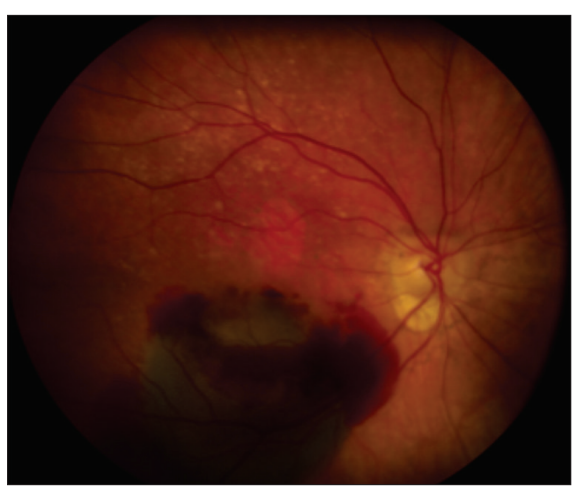

Figure 2: Color picture showing subretinal hemorrhage

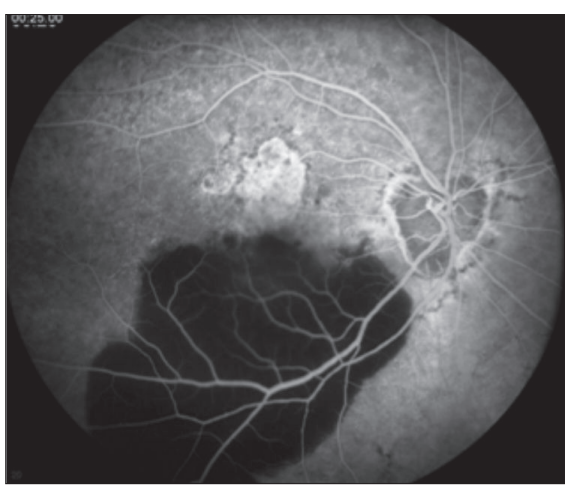

Figure 3: Fluorescein angiography showing blockage of dye due subretinal hemorrhage
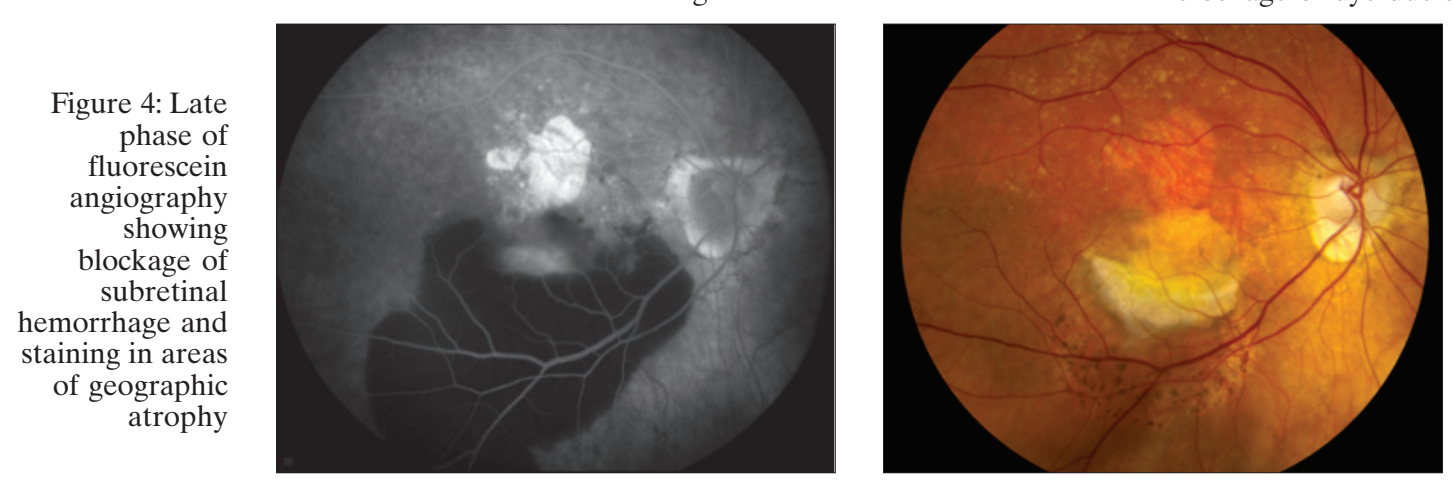

Figure 5:

Color picture showing reabsortion of hemorrhage and residual subretinal fibrosis 
verteporfin, intravitreal pegaptanib or intravitreal ranibizumab specifically excluded this type of lesion. ${ }^{17-20}$ Data from MARINA and ANCHOR trials for predominantly hemorrhagic lesions must be performed with caution as it is unclear whether the efficacy of ranibizumab for predominantly hemorrhagic lesions is modulated by the presence of large areas of subretinal blood. ${ }^{19,20}$

Current research has not indicated whether these drugs can penetrate the target site of the CNV. Although clinical trials have provided no effective treatments for predominantly hemorrhagic lesions, submacular surgery trials (SST) found that surgery for hemorrhages and associated CNV did not improve or stabilize vision. $^{2}$ A report of a case series reported that the visual acuity of the subjects treated may have been limited through pre-existing retinal damage and subretinal fibrosis due to $\mathrm{CNV}$ or the subsequent loss of retinal tissue from the hemorrhage or from the ensuing fibrotic destruction of retinal tissue. ${ }^{15}$

Intravitreal bevacizumab and ranibizumab therapy for predominantly hemorrhagic $\mathrm{CNV}$ has been reported. ${ }^{(15,16)} \mathrm{A}$ case series of bevacizumab in 21 eyes of 19 patients found an improvement in the Snellen VA based on at least a single letter improvement in $48 \%$ of the treated eyes, no letter changes in $9 \%$, and a single letter or greater decrease in the Snellen VA in $43 \%$ of subjects, 4 months following the first injection ${ }^{(17)}$. The median VA did not change from baseline to 4 months and remained at 20/100. When 12 of these eyes were followed for 1 year, only $25 \%$ maintained an improvement in vision, $17 \%$ displayed no changes and $58 \%$ lost at least a single letter of vision. In the ranibizumab series at 12 months, the median visual acuity letter score was 30 (Snellen equivalent: 20/250), with a median change from baseline to last follow-up of +7 letters. ${ }^{16}$ Three of 7 subjects ( $43 \%$ ) gained 2 or more lines of vision, whilst no subjects lost 2 or more lines. Three months of treatment with Sulfur hexafluoride gas, an intravitreal tissue plasminogen activator, and bevacizumab injection in 19 patients with relatively small hemorrhagic lesions, improved the mean VA from 20/133 to $20 / 74^{(21)}$. However, this study included only small sized hemorrhages and no extended follow up was performed.

In the present case, monthly ranibizumab (six intravitreal injections) displayed a promising response but this limited report is insufficient to guarantee the indication for all predominantly hemorrhagic choroidal neovascular lesions from CNV due to AMD. Further studies will be necessary for complete validation of our results.

\section{Acknowledgement}

To professor James Folk, MD, chief of the Vitreoretina service of Iowa University

\section{REFERENCES}

1. Solomon SD, Bressler SB, Hawkins BS, Marsh MJ, Bressler NM; Submacular Surgery Trials Research Group. Guidelines for interpreting retinal photographs and coding findings in the Submacular Surgery Trials (SST): SST report no. 8. Retina. 2005;25(3):253-68.

2. Bressler NM, Bressler SB, Childs AL, Haller JA, Hawkins BS, Lewis H, MacCumber MW, Marsh MJ, Redford M,Sternberg P Jr,Thomas MA, Williams GA; Submacular Surgery Trials (SST) Research Group. Surgery for hemorrhagic choroidal neovascular lesions of age-related macular degeneration: ophthalmic findings: SST report no. 13. Ophthalmology. 2004;111(11):1993-2006

3. Bennett SR, Folk JC, Blodi CF, Klugman M. Factors prognostic of visual outcome in patients with subretinal hemorrhage. Am J Ophthalmol. 1990;109(1):33-7.

4. Avery RL, Fekrat S, Hawkins BS, Bressler NM. Natural history of subfoveal subretinal hemorrhage in age-related macular degeneration. Retina. 1996;16(3):183-9

5. Glatt H, Machemer R. Experimental subretinal hemorrhage in rabbits. Am J Ophthalmol. 1982;94(6):762-73.

6. Gass JD. Stereoscopic atlas of macular diseases: diagnosis and treatment. 4th ed. St. Louis: Mosby; 1997. p. 49-70
7. Gass JD. Choroidal neovascular membranes--their visualization and treatment. Trans Am Acad Ophthalmol Otolaryngol. 1973;77(3):OP310-20.

8. Chen CY, Hooper C, Chiu D, Chamberlain M, Karia N, Heriot WJ. Management of submacular hemorrhage with intravitreal injection of tissue plasminogen activator and expansile gas. Retina. 2007:27(3):321-8.

9. Hassan AS, Johnson MW, Schneiderman TE, Regillo CD, Tornambe $\mathrm{PE}$, Poliner LS, et al. Management of submacular hemorrhage with intravitreous tissue plasminogen activator injection and pneumatic displacement. Ophthalmology. 1999;106(10):1900-6; discussion 19067. Comment in Ophthalmology. 2000;107(12):2118-9. Ophthalmology. 2000;107(12):2119-20.

10. Hattenbach LO, Klais C, Koch FH, Gümbel HO. Intravitreous injection of tissue plasminogen activator and gas in the treatment of submacular hemorrhage under various conditions. Ophthalmology. 2001;108(8):1485-92. Comment in Ophthalmology. 2002;109(5):824; author reply 825

11. Hattenbach LO, Brieden M, Koch F, Gümbel H. [Intravitreal injection of rt-PA and gas in the management of minor submacular hemorrhages secondary to age-related macular degeneration].Klin Monatsbl Augenheilkd. 2002;219(7):512-8. German.

12. Handwerger BA, Blodi BA, Chandra SR, Olsen TW, Stevens TS. Treatment of submacular hemorrhage with low-dose intravitreal tissue plasminogen activator injection and pneumatic displacement. Arch Ophthalmol. 2001;119(1):28-32. Comment in Arch Ophthalmol. 2002;120(1):102-3; author reply 203.

13. Hesse L, Schmidt J, Kroll P. Management of acute submacular hemorrhage using recombinant tissue plasminogen activator and gas. Graefes Arch Clin Exp Ophthalmol. 1999;237(4):273-7.

14. Schulze SD, Hesse L. Tissue plasminogen activator plus gas injection in patients with subretinal hemorrhage caused by age-related macular degeneration: predictive variables for visual outcome. Graefes Arch Clin Exp Ophthalmol. 2002;240(9):717-20.

15. Stifter E,Michels S, Prager F, Georgopoulos M,Polak K, Hirn C, SchmidtErfurth U. Intravitreal bevacizumab therapy for neovascular age-related macular degeneration with large submacular hemorrhage. Am J Ophthalmol. 2007;144(6):886-92.

16. Chang MA, Do DV, Bressler SB, Cassard SD, Gower EW, Bressler NM. Prospective one-year study of ranibizumab for predominantly hemorrhagic choroidal neovascular lesions in age-related macular degeneration. Retina. 2010;30(8):1171-6. Comment in Retina. 2011;31(9):1749-52.

17. Blinder KJ,Bradley S, Bressler NM, Bressler SB, Donati G,Hao Y,Ma C, Menchini U, Miller J, Potter MJ, Pournaras C, Reaves A, Rosenfeld PJ, Strong HA, Stur M, Su XY, Virgili G; Treatment of Age-related Macular Degeneration with Photodynamic Therapy study group; Verteporfin in Photodynamic Therapy study group. Effect of lesion size, visual acuity, and lesion composition on visual acuity change with and without verteporfin therapy for choroidal neovascularization secondary to age-related macular degeneration:TAP and VIP report no. 1. Am J Ophthalmol. 2003;136(3):407-18.

18. Gragoudas ES, Adamis AP, Cunningham ET Jr,Feinsod M, Guyer DR; VEGF Inhibition Study in Ocular Neovascularization Clinical Trial Group. Pegaptanib for neovascular age-related macular degeneration. N Engl J Med. 2004:351(27):2805-16. Comment in ACP J Club. 2005;143(1):18. N Engl J Med. 2005;352(16):1720-1; author reply 17201. N Engl J Med. 2004;351(27):2863-5.

19. Rosenfeld PJ,Brown DM, Heier JS, Boyer DS, Kaiser PK, Chung CY, Kim RY; MARINA Study Group. Ranibizumab for neovascular age-related macular degeneration. N Engl J Med. 2006;355(14): 1419-31. Comment in N Engl J Med. 2006; 355(14):1409-12. N Engl J Med. 2007; 356(7):7489; author reply 749-50. N Engl J Med. 2007;356(7):747-8; author reply 749-50. N Engl J Med. 2006; 355 (14):1493-5.

20. Brown DM,Kaiser PK, Michels M, Soubrane G,Heier JS, Kim RY,Sy JP Schneider S;ANCHOR Study Group. Ranibizumab versus verteporfin for neovascular age-related macular degeneration. N Engl J Med. 2006;355(14):1432-44. Comment in N Engl J Med. 2006;355(14):140912. N Engl J Med. 2007:356(7):748-9; author reply 749-50. N Engl J Med. 2007;356(7):747-8; author reply 749-50. N Engl J Med. 2006;355(14):1493-5.

21. Meyer CH, Scholl HP, Eter N, Helb HM, Holz FG. Combined treatment of acute subretinal haemorrhages with intravitreal recombined tissue plasminogen activator, expansile gas and bevacizumab: a retrospective pilot study. Acta Ophthalmol. 2008;86(5):490-4. 